\title{
Gambaran Pengetahuan, Sikap, dan Perilaku Kader Palang Merah Remaja (PMR) di SMAN 2 Lamongan Terhadap Program Suplementasi Tablet Tambah Darah
}

\section{Description of Knowledge, Attitudes, and Behavior of Youth Red Cross Cadres (PMR) in SMAN 2 Lamongan Toward the Iron-Folic Acid Supplementation Program}

\author{
Stefania W. Setyaningtyas*, Thinni N. Rochmah, Trias Mahmudiono, Susi Hidayah, Yurike D. Adhela
}

\begin{abstract}
ABSTRAK
Latar Belakang: penanggulangan anemia dengan pemberian Tablet Tambah Darah (TTD) dengan sasaran remaja putri menjadi fokus pemerintah saat ini. Walaupun sudah mulai berjalan, seringkali ditemukan beberapa kendala dalam pelaksanaan program, diantaranya ketidakpatuhan konsumsi TTD. Di sisi lain, sekolah memiliki potensi sumberdaya untuk meningkatkan optimalisasi program TTD, salah satunya adalah Palang Merah Remaja (PMR) yang dapat menjadi pendidik sebaya tentang masalah kesehatan termasuk anemia bagi siswi lainnya.

Tujuan: Penelitian ini bertujuan melihat gambaran pengetahuan, sikap, dan perilaku kader PMR di SMA Negeri 2 Lamongan terhadap program pemberian TTD

Metode: Penelitian ini merupakan menggunakan desain cross sectional. Populasi penelitian ini adalah anggota ekstrakurikuler Palang Merah Remaja (PMR) SMAN 2 Lamongan sejumlah 100 orang. Sampel dari penelitian ini adalah 60 siswa anggota PMR yang dipilih dengan metode simple random sampling dan memenuhi kriteria inklusi yaitu merupakan anggota aktif PMR dan bersedia mengikuti penelitian. Pengumpulan data dilakukan dengan menggunakan self-administered questionnaires dengan menggunakan aplikasi kuesioner online yang terdiri dari 20 pertanyaan untuk mengukur pengetahuan; 20 pertanyaan untuk mengukur sikap; dan 13 pertanyaan untuk mengukur perilaku. Data dikategorikan dan dianalisis menggunakan uji deskriptif. Hasil: Sebagian besar responden masih memiliki pengetahuan yang kurang terkait program TTD (56,7\%) dan manfaatnya (56,7\%). Sebesar 66\% kader PMR memiliki sikap yang positif terhadap TTD, namun tidak $100 \%$ kader PMR mengonsumsi tablet tambah darah secara rutin.

Kesimpulan: Perlu penguatan terhadap pengetahuan serta sikap terhadap TTD untuk meningkatkan kepatuhan konsumsi TTD di kalangan anggota PMR agar nantinya kader PMR dapat menjadi pendidik sebaya bagi siswi lainnya.
\end{abstract}

Kata kunci: anemia, peer educator, pengetahuan, sikap, perilaku

\section{ABSTRACT}

Background: anemia prevention through iron-folic acid supplementation (IFA) for female adolescent has become goverment's program priority. Although this programme have been running, several constrains including consumption compliance was frequently found. On the other hand, school have potential resources such as Junior of The Red Cross (PMR) which can be peer educator for health including anemia for other students.

Objectives: this research was aimed to describe knowledge, practice, and attitude of PMR member toward IFA supplementation in SMAN 2 Lamongan

Methods: This research used cross sectional design. The population of this study was 100 members of the Red Cross Youth Teaching (PMR) SMAN 2 Lamongan. The sample of this study was 60 students who were selected by the simple random sampling method who met the inclusion criteria, such as were active members of the PMR and were willing to take part in the study. Data collection was carried out using self-administered questionnaires using an online questionnaire application consisting of 20 questions to measure knowledge; 20 questions to measure attitude; and 13 questions to measure behavior. Data were categorized and analyzed using descriptive tests.

Results: Most respondents still have lack of knowledge related to the TTD program (56.7\%) and its benefits (56.7\%). 66\% of PMR cadres have a positive attitude towards TTD, but not 100\% of PMR cadres consume blood-added tablets regularly.

Conclusions Strengthening of knowledge and attitudes towards TTD is needed to improve compliance of TTD consumption among PMR members so that later PMR cadres can become peer educators for other students.

Keywords: anemia, peer educator, knowledge, attitude, practice 


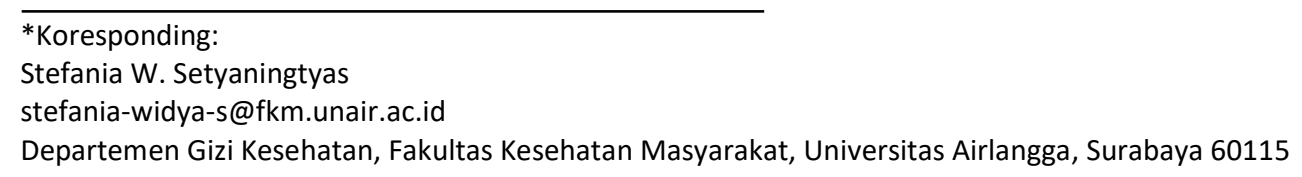

\section{PENDAHULUAN}

Anemia merupakan salah satu masalah kesehatan masyarakat di Indonesia yang hingga saat ini belum teratasi ${ }^{1}$. Terjadi peningkatan prevalensi anemia sekitar 7\% dari tahun 2007 dimana diketahui prevalensi anemia sebesar $14,8 \%$ menjadi $21,7 \%$ di tahun $2013^{1,2}$.

Wanita pada usia subur, termasuk remaja perempuan adalah salah satu kelompok berisiko tinggi untuk anemia. Penurunan kadar hemoglobin lazim ditemukan pada remaja putri karena siklus menstruasi. Sebuah penelitian di India memperlihatkan bahwa lebih dari $60 \%$ wanita di usia remaja mengalami anemia ${ }^{3}$. Prevalensi anemia di kalangan perempuan berusia 15 - 49 tahun di Indonesia adalah $30 \%^{2}$. Berdasarkan Survei Kesehatan Rumah Tangga (SKRT) pada tahun 2004, hampir $40 \%$ remaja perempuan berusia 2-19 tahun mengalami anemia. Sementara Riset Kesehatan Dasar (Riskesdas) pada 2007 mengungkapkan bahwa prevalensi anemia pada remaja perempuan (berusia $\geq 15$ tahun) di kota-kota perkotaan adalah 19,7\%. Prevalensi berdasarkan Riskesdas 2013 adalah 35,3\% di antara wanita berusia 15 - 44 tahun ${ }^{2}$.

Anemia defisiensi zat besi merupakan manifestasi klinis dari menurunnya cadangan zat besi di dalam tubuh, dikarenakan rendahnya asupan zat besi dari makanan. Dampak dari anemia ini adalah menurunnya kapasitas kerja, dan ketahanan fisik, penurunan imunitas, gangguan gastrointestinal dan gangguan neurokognitif ${ }^{4}$. Oleh sebab itu, anemia perlu ditanggulangi sejak dini untuk mencegah kerugian yang disebabkan oleh penyakit ini.

Untuk mengatasi masalah anemia, pemerintah Indonesia melalui Departemen Kesehatan memberikan program suplemen zat besi yang menargetkan remaja perempuan. Pemberian suplemen TTD yang berisi unsur besi $60 \mathrm{mg}$ dalam bentuk Ferro Sulfat atau Ferro Fumarat dan $0,400 \mathrm{mg}$ asam folat ${ }^{1}$. Program pemberian tabelt tambah darah (TTD) bagi remaja putri tidak berjalan tanpa kendala. Beberapa penelitian menunjukkan salah satu kendala yang sering ditemui dari program pemberian TTD adalah masalah kepatuhan. Remaja putri seringkali tidak patuh dalam mengonsumsi tablet tambah darah karena berbagai alasan. Untuk mengatasi hal tersebut perlu dilakukan berbagai upaya seperti dengan memberikan sosialisasi diawal pemberian, membuat program konsumsi TTD bersama petugas kesehatan, dan memberikan pesan singkat melalui media komunikasi untuk mengingatkan pentingnya kosumsi TTD secara rutin $^{5}$. Kepatuhan dinilai sebagai salah satu faktor kunci yang memegang peran esensial dalam keberhasilan pencegahan anemia melalui TTD. Kepatuhan dinilai dari ketepatan jumlah dan frekuensi konsumsi TTD sesuai anjuran.

Rendahnya kepatuhan konsumsi TTD pada remaja putri dipengaruhi oleh beberapa faktor salah satunya oleh pengetahuan siswi terkait manfaat mengonsumsi TTD. Masalah gizi pada remaja seringkali muncul sebagai dampak dari kurangnya pengetahuan dan kesadaran dalam mencukupi zat gizi. Pengetahuan akan mempengaruhi sikap dan perilaku remaja dalam memilih makanan, mengonsumsi suplementasi TTD, dan selanjutnya akan berpengaruh terhadap kondisi gizi individu secara keseluruhan termasuk kondisi status anemia $^{6}$. Di samping itu, berbagai efek samping dari mengonsumsi TTD seperti sakit perut, mual, pusing, dan rasa yang kurang enak banyak dikemukakan oleh para remaja putri. Hal tersebut kemudian membuat mereka merasa kurang nyaman dan turut mempengaruhi motivasi siswi untuk mengonsumsi TTD 7 .

Pencapaian keberhasilan program kesehatan tidak dapat dilakukan sendiri oleh sektor kesehatan saja. Dalam beberapa program kesehatan berbasis sekolah, sekolah dan elemennya yaitu para guru memegang peranan strategis dalam menyukseskan program kesehatan termasuk didalamya program suplementasi tablet tambah darah ${ }^{8}$. Oleh karena itu, keterlibatan aktif unsur sekolah diharapkan dapat meningkatkan kesadaran serta motivasi siswi untuk mengonsumsi TTD.

Salah satu unsur potensial yang ada di sekolah adalah Palang Merah Remaja (PMR). PMR merupakan salah satu kegiatan ekstrakurikuler yang ada di hampir setiap sekolah. Dalam PMR, anggota diajarkan beberapa konsep dasar kesehatan dan pertolongan pertama, namun sayangnya, topik gizi masih jarang diintegrasikan dalam setiap kegiatan PMR. Kader PMR yang memiliki ketertarikan lebih terhadap kesehatan dapat menjadi mitra potensial dalam menguatkan pelaksanaan program pemberian TTD di sekolah dengan menambahkan peran PMR di sekolah sebagai pendidik sebaya atau peer educator.

Pendidikan sebaya adalah suatu pengajaran yang ditujukan untuk berbagi informasi, nilai - nilai, dan perilaku dalam sebuah kelompok dengan anggota yang mempunyai umur atau status yang sama. Interaksi yang dilakukan antar remaja memungkinkan terjadinya komunikasi yang lebih terbuka dan lebih relevan dengan budaya serta perkembangan yang ada ${ }^{9}$. Efektifitas pendidikan sebaya dalam mengubah perilaku kesehatan seseorang telah dibuktikan di beberapa penelitian diantaranya penelitian Rofi'ah et al (2017) tentang metode pendidikan sebaya dalam memperbaiki pengetahuan kesehatan pada remaja ${ }^{10}$. Hasil penelitian tersebut menyatakan bahwa pendidikan dengan metode pendidikan sebaya dapat memperbaiki pengetahuan remaja tentang personal hygiene saat menstruasi sehingga, dapat memperbaiki personal hygiene para remaja dan terjadi perubahan sikap pada para remaja. Dalam pelaksanaan pendidikan sebaya diperlukan dukungan yag besar dari pihak eksternal seperti guru atau orang tua ${ }^{10}$. Penelitian ini bertujuan untuk memberikan gambaran pengetahuan, sikap, dan perilaku remaja putri terhadap program pemberian TTD di SMA Negeri 2 Lamongan. 


\section{METODE}

Penelitian ini merupakan penelitian observasional analitik dengan desain rancangan studi potong lintang (cross sectional). Penelitian ini dilaksanakan di SMA Negeri 2 Lamongan, Kabupaten Lamongan, Jawa Timur. Populasi penelitian ini adalah anggota ekstrakurikuler Palang Merah Remaja (PMR) SMAN 2 Lamongan sejumlah 100 orang. Sampel dari penelitian ini adalah 60 siswa anggota PMR yang dipilih dengan metode simple random sampling dan memenuhi kriteria inklusi yaitu merupakan anggota aktif PMR dan bersedia mengikuti penelitian. Kriteria eksklusi yaitu jika siswa pindah sekolah selama penelitian berlangsung.

Pengumpulan data dilakukan dengan menggunakan self-administered questionnaires dengan menggunakan aplikasi kuesioner online yang terdiri dari 20 pertanyaan untuk mengukur pengetahuan (Cronbach's $\alpha=0,703$ ); 20 pertanyaan untuk mengukur sikap (Cronbach's $\alpha=0,754$ ); dan 13 pertanyaan untuk mengukur perilaku (Cronbach's $\alpha=0,625$ ). Pengetahuan dikatakan baik apabila responden mampu menjawab dengan benar $>80 \%$ pertanyaan pengetahuan yang diajukan; sedang bila mampu menjawab $50-80 \%$ pertanyaan; dan kurang bila responden menjawab $<50 \%$ pertanyaan dengan benar. Pertanyaan seputar sikap dinyatakan dalam skala likert dengan 5 interval dari sangat tidak setuju hingga sangat setuju. Pengukuran praktik konsumsi TTD ditanyakan melalui pernyataan yang harus dijawab dengan respon "ya" atau "tidak" oleh responden. Hasil penelitian disajikan dalam bentuk deskriptif dalam bentuk sebaran $\mathrm{n} \%$ dan diolah menggunakan software Microsoft Excel dan SPSS versi 22. Selain itu, uji korelasi spearman juga dilakukan untuk melihat korelasi antar variabel.

\section{HASIL DAN PEMBAHASAN}

Keberhasilan suatu program pencegahan masalah kesehatan masyarakat sangat bergantung pada kesadaran dan dukungan sosial dari kelompok terpapar maupun masyarakat. Penelitian di India dan ethiopia memperlihatkan bahwa membentuk kesadaran tentang diet tinggi zat besi dan konsumsi tablet tambah darah diantara ibu hamil memberikan dampak positif terhadap pencegahan kejadian anemia ${ }^{11,12}$. Penelitian lain membuktikan bahwa pengetahuan mengenai penyebab dan dampak masalah kesehatan akan membentuk kesadaran seseorang terkait pencegahan anemia ${ }^{13}$.

Program suplementasi tablet tambah darah telah dilaksanakan di SMA Negeri 2 Lamongan sejak tahun 2019. Meskipun telah dilaksanakan di sekolah, namun belum ada kegiatan sosialisasi khusus yang dilakukan untuk mendukung cakupan konsumsi TTD. Sebagai salah satu kader kesehatan di sekolah, PMR memiliki peranan signifikan sebagai edukator kesehatan bagi teman sebayanya di sekolah. Di Indonesia, program suplementasi ini dilakukan dengan kombinasi konsumsi TTD mingguan dan harian ${ }^{14}$.

Walaupun memiliki peran strategis, nyatanya masih banyak kader PMR yang belum memiliki cukup pengetahuan terkait program TTD pada remaja putri yang ditujukan untuk mencegah anemia ini. Gambaran pengetahuan kader PMR terhadap program TTD dapat dilihat pada tabel 1 dibawah ini. Kurangnya pengetahua mengenai anemia ini akan berimplikasi pada kurangnya kesadaran siswa, baik siswa PMR maupun non PMR untuk mengonsumsi Tablet Tambah Darah ${ }^{15}$. Hal ini didukung oleh hasil uji bivariat yang menunjukkan pengetahuan mengenai program TTD berhubungan signifikan $(R=0.3$; $\mathrm{P}=0.022$ ) dengan perilaku konsumsi TTD di kalangan kader PMR (Tabel 4). Hasil yang sejalan juga ditemukan pada penelitian lain yang menunjukkan hubungan yang signifikan antara pengetahuan dengan perilaku konsumsi TTD ${ }^{16-19}$.

Secara umum, sebagian besar kader PMR belum memiliki pengetahuan mengenai program TTD dan manfaat dari program TTD dengan baik. Secara terperinci, data pada tabel 1 menunjukkan bahwa sebagian kader PMR masih memiliki persepsi yang salah mengenai tablet tambah darah, dimana lebih dari separuh kader PMR masih menganggap tablet tambah darah merupakan pemicu darah tinggi ( 35 dari 60 responden). Selain itu, 38 dari 60 kader masih beranggapan bahwa tablet tambah darah perlu dikonsumsi setiap hari, dan $50 \%$ responden masih memiliki pengetahuan yang terbatas mengenai waktu yang paling tepat untuk mengonsumsi TTD. Meskipun masih ada beberapa pengetahuan yang salah mengenai TTD, namun sebagian besar kader PMR telah menyadari bahwa kebutuhan zat besi meningkat selama menstruasi dan TTD adalah salah satu alternatif yang digunakan untuk mencegah anemia.

Tabel 1. Gambaran Pengetahuan Kader PMR terhadal Tablet Tambah Darah

Pertanyaan
Menstruasi menyebabkan peningkatan kebutuhan zat besi pada remaja pla
TTD berfungsi untuk mencegah kurang darah
Konsumsi TTD menyebabkan peningkatan tekanan darah
Konsumsi TTD dapat meningkatkan konsentrasri belajar
TTD harus diminum setiap hari selama menstruasi
TTD harus diminum setiap hari walaupun tidak menstruasi
TTD sebaiknya dikonsumsi sebelum tidur untuk menghindari rasa mual
TTD sebaiknya dikonsumsi bersama jeruk
TTD sebaiknya dikonsumsi bersama teh atau kopi
Konsumsi TTD sesuai anjuran berbahaya bagi kesehatan

Konsumsi TTD sesuai anjuran berbahaya bagi kesehatan

\begin{tabular}{ll}
\cline { 1 - 1 } Jawaban Benar & Jawabah Salah \\
\hline 49 & 10 \\
55 & 5 \\
25 & 35 \\
51 & 8 \\
46 & 14 \\
51 & 8 \\
22 & 38 \\
30 & 30 \\
56 & 4 \\
54 & 6
\end{tabular}


Gambaran sikap kader PMR mengenai TTD dapat dilihat pada tabel 2 dibawah ini. sebagian besar kader PMR memiliki sikap positif tentang TTD, dimana mereka yakin dengan mengonsumsi TTD, mereka mampu mencegah anemia dan efek samping lainnya yang disebabkan oleh anemia. Walaupun demikian, masih terdapat $34 \%$ responden yang memiliki sikap negatif terkait TTD. Hal ini mengindikasikan masih perlu penguatan baik pengetahuan maupun sikap kader PMR terhadap peran TTD dalam pencegahan anemia dan pemeliharaan kesehatan. Sikap responden terhadap konsumsi TTD memiliki korelasi bermakna $(R=0.4$; $P=$ 0.001 ) dengan perilaku konsumsi TTD (Tabel 4). Hal ini juga ditemukan pada penelitian lain yang mengungkapkan keeratan hubungan antara sikap dengan kepatuhan konsumsi TTD20,21.

Tabel 2. Sikap Kader PMR terhadap Tablet Tambah Darah

\begin{tabular}{ll} 
Sikap terhadap TTD & $\mathbf{N}(\%)$ \\
\hline Positif & $40(66)$ \\
Negatif & $20(34)$ \\
\hline
\end{tabular}

Pada tabel 3, terlihat bahwa tidak $100 \%$ kader PMR mengonsumsi tablet tambah darah secara rutin. Separuhnya masih merasa bahwa aroma TTD yang tidak enak menghalangi mereka untuk mengonsumsi TTD. Selain itu, hasil penelitian ini menunjukkan bahwa masih ada beberapa kader yang mengalami efek samping akibat konsumsi TTD. Hal ini mengindikasikan mereka belum mengetahui cara minum TTD yang benar.

Tabel 3. Praktek Kader PMR Terkait Konsumsi TTD

Pertanyaan

$Y a(n(\%))$

$31(52 \%)$

Tidak (n(\%))

Saya mengonsumsi tablet tambah darah $1 x /$ hari saat menstruasi dan $1 x /$ minggu saat tidak menstruasi

Aroma dan rasa tablet tambah darah yang tidak enak membuat saya kurang menyukai dan tidak mengonsumsi tablet tambah darah

Setelah mengonsumsi tablet tambah darah saya merasakan efek samping seperti mual, pusing, atau susah buang air besar

Setelah mengonsumsi tablet tambah darah saya merasakan efek samping seperti mual, pusing, atau susah buang air besar

Saya mengonsumsi makanan sumber Fe seperti ikan, telur, ayam, atau hati karena saya mengetahui makanan tersebut kaya akan zat besi

Berdasarkan pertanyaan yang diajukan kepada kader PMR, hanya 1 orang yang mengetahui manfaat makanan sumber zat besi seperti ikan, telur, dan ayam atau hati untuk menanggulangi anemia. Hal ini membuktikan bahwa masih perlu penguatan terhadap siswi, terutama kader PMR sebagai salah satu agen kesehatan di lingkungan sekolah mengenai manfaat serta praktek konsumsi TTD maupun makanan sumber zat besi. Hasil penelitian yang sama juga ditemukan oleh Siyam dan Woro (2014) yang menunjukkan rendahnya literasi dan kesadaran gizi pada kader kesehatan remaja di sekolah ${ }^{22}$. Penelitian lain mengungkapkan bahwa kader kesehatan remaja memiliki peran potensial sebagai edukator kesehatan sebaya untuk meningkatkan konsumsi TTD pada remaja putri ${ }^{23}$. Pengawasan langsung meningkatkan kepatuhan konsumsi TTD dalam rangka pencegahan anemia. Kader kesehatan sekolah merupakan potensi sumber daya yang dapat libatkan dalam pengawasan minum TTD pada remaja putri ${ }^{24}$.

Tabel 4. Korelasi Antara Perilaku Konsumsi TTD dengan Pengetahuan dan Sikap terkait TTD

\begin{tabular}{l|ll} 
Variabel & $R$ & $P$ \\
\hline Pengetahuan terkait TTD & 0.295 & $0.022^{*}$ \\
Sikap terkait TTD & 0.406 & $0.001^{*}$
\end{tabular}

Ket : Uji dilakukan dengan korelasi spearman; *) signifikan $(p<0.05)$

(C)2020. Setyaningtyas, dkk. Open access under CC BY - SA license.

Received: 15-01-2020, Accepted: 02-04-2020, Published online: 29-09-2020.

doi: 10.20473/amnt. v4i3.2020.213-217 . Joinly Published by IAGIKMI \& Universitas Airlangga

\section{KESIMPULAN}

Meskipun pengetahuan dan sikap terhadap TTD dari kader PMR sebagian besar sudah cukup baik, namun pada prakteknya masih banyak anggota PMR yang belum melaksanakan program pencegahan anemia sesuai anjuran. Perlu penguatan terhadap pengetahuan serta sikap terhadap TTD untuk meningkatkan kepatuhan konsumsi TTD di kalangan anggota PMR.

Anggota PMR adalah salah satu potensi untuk menjadi media penyampaian informasi gizi dan kesehatan kepada siswa di sekolah. Oleh karena itu, pelatihan intensif dapat memungkinkan PMR menjadi pendidik sebaya bagi rekan sesama siswa untuk meningkatkan derajat kesehatan, salah satunya melalui kepatuhan konsumsi Tablet Tambah Darah.

\section{ACKNOWLEDGEMENT}

Terima kasih penulis sampaikan kepada seluruh pihak yang telah mendukung kelancaran program pengabdian masyarakat ini yaitu Universitas Airlangga yang telah memberikan bantuan dana untuk menunjang pelaksanaan program, Kepala sekolah, bapak/ibu guru, dan siswa-siswi SMA Negeri 2 Lamongan telah bersedia 
untuk menjalalin kerjasama dan berpartisipasi aktif selama pelaksanaan program. Pihak Bakesbangpol dan Dinas Kesehatan Kabupaten Lamongan yang telah memberikan ijin pelaksaan kegiatan

\section{Referensi}

1. Ministry of Health Republic of Indonesia. Riset Kesehatan Dasar (RISKESDAS) 2013. (2013). doi:1 Desember 2013

2. Ministry of Health Republic of Indonesia. Riset Kesehatan Dasar (RISKESDAS) 2007. (2007). doi:1 Desember 2007

3. Toteja, G. S. et al. Prevalence of anemia among pregnant women and adolescent girls in 16 districts of India. Food Nutr. Bull. 27, 311-315 (2006).

4. Clark, S. F. \& Clark, S. F. Iron Deficiency Anemia Susan. Nutr Clin Pr. 23, (2008).

5. Fikawati, S. et al. Pengaruh suplementasi zat besi satu dan dua kali per minggu terhadap kadar hemoglobin pada siswi yang menderita anemia. Universa Med. 24, 167-174 (2004).

6. Lestari, P. Hubungan PengetahuanDengan Konsumsi Tablet Fe Saat Menstruasi Pada Remaja Putri Di SMA N 2 Banguntapan Bantul. (Universitas Sebelas Maret, 2012).

7. Priya, S. H. et al. Factors influencing weekly iron folic acid supplementation programme among school children : Where to focus our attention? Saudi J. Heal. Sci. 5, 28-33 (2016).

8. Zavaleta, N., Respicio, G. \& Garcia, T. Improving Adolescent Iron Status before Childbearing Efficacy and Acceptability of Two Iron Supplementation Schedules in. J Nutr 130, 462464 (2000).

9. Stephenson, J. et al. The Long-Term Effects of a Peer-Led Sex Education Programme ( RIPPLE ): A Cluster Randomised Trial in Schools in England. Plos Med. 5, (2008).

10. Rofi'ah, S., Widatiningsih, S. \& Vitaningrum, D. Efektivitas pendidikan kesehatan metode peer group terhadap tingkat pengetahuan dan sikap personal hygiene saat menstruasi. J. IIm. Bidan II, 31-36 (2017).

11. Balasubramanian, T., Aravazhi, M. \& Sampath, S. D. Awareness of Anemia among Pregnant Women and Impact of Demographic Factors on their Hemoglobin Status. Int. J. Sci. Study $\mathbf{3}$, 303-305 (2016).

12. Gebre, A. \& Mulugeta, A. Prevalence of Anemia and Associated Factors among Pregnant Women in North Western Zone of Tigray, Northern Ethiopia : A Cross-Sectional Study. J. Nutr. Metab. 2015, 1-7 (2015).

13. Hussain, T., Shu, L. Y. \& Hospital, U. Awareness of Iron Deficiency Anemia among women of Reproductive age in Hubei Province, China.
ASIAN J. Med. Sci. 1, 12-13 (2010).

14. Susanti, Y., Briawan, D. \& Martianto, D. SUPLEMENTASI BESI MINGGUAN MENINGKATKAN HEMOGLOBIN. J. Gizi Pangan 11, 27-34 (2016).

15. Wiradnyani, L. A., Khusun, H. \& Achadi, E. L. Faktor-faktor yang berhubungan dengan kepatuhan ibu mengonsumsi tablet besi-folat selama kehamilan. J. Gizi dan Pangan 8, 63-70 (2013).

16. Wahyuningsih, A. \& Uswatun, A. Hubungan pengetahuan tentang anemia dengan kepatuhan mengkonsumsi tablet tambah darah remaja putri di sma negeri 1 karanganom. $J$. Involusi Kebidanan 9, 4-13 (2019).

17. Taye, B., Abeje, G. \& Mekonen, A. Factors associated with compliance of prenatal iron folate supplementation among women in Mecha district, Western Amhara: a crosssectional study. Pan Afr. Med. J. 20, 1-7 (2015).

18. Ugwu, E. O., Olibe, A. O., Obi, S. N. \& Ugwu, A. $O$. Determinants of compliance to iron supplementation among pregnant women in Enugu, Southeastern Nigeria. Niger. J. Clin. Pract. 17, 608-612 (2014).

19. Mora, J. O. Iron Supplementation : Overcoming Technical and Practical Barriers. J. Nutr. 132, 853-855 (2002).

20. Setyobudihono, S. Hubungan Sikap dan Norma Subyektif dengan Niat Mengkonsumsi Tablet Suplementasi Besi Pada Ibu Hamil di Banjarmasin. J. Psikol. Teor. Terap. 4, 106-112 (2014).

21. Puspasari, F. D., Saryono \& Ramawati, D. Faktorfaktor yang mempengaruhi kepatuhan ibu hamil dalam mengkonsumsi tablet besi di Desa Sokaraja Tengah Kecamatan Sokaraja Kabupaten Banyumas. (The Soedirman J. Nurs. 3, 25-31 (2008).

22. Siyam, N. \& Woro, O. Training of Healthy Adolescent Cadre (HAC) As Efforts to Increase Student Health of Islamic Junior High School Walisongo Kedungwuni Year 2014. in First International Seminar on Public Health and Education 177-186 (Public Health Department Faculty of Sport Science Semarang State University, 2014).

23. Amareta, D. I. et al. Regression Modelling Based on Characteristicsof Anemia in Female Adolescent. in The First International Conference of Food and Agriculture 594-598 (State Polytechnic Jember, 2018).

24. Bairwa, M. et al. Directly Observed Iron Supplementation for Control of Iron Deficiency Anemia. Indian J. Public Health 61, 37-42 (2017). 